УДК 070

ББК 76.02

\section{O.A. Болтуц}

\section{ПОВСЕДНЕВНАЯ ЖИЗНЬ ЧЕРНОМОРСКОЙ ГУБЕРНИИ НА СТРАНИЦАХ ГАЗЕТЫ «СЕВЕРНЫЙ КАВКАЗ "}

Анализируются периодика Черноморской губернии рубежа XIX XX вв., рассматриваются особенности редакционной политики газеты «Северный Кавказ» в освещении повседневной жизни Черноморской губернии.

Ключевые слова: Черноморская губерния, периодика, Ф.С.Леонтович, «Новороссийский листок», «Черноморское побережье», «Северный Кавказ», редакционная политика, повседневная жизнь.

DOI 10.18522/1995-0640-2020-1-227-232
Болтуц Ольга Александровна - канд. филол. наук, доцент кафедры истории и правового регулирования массовых коммуникаций факультета журналистики Кубанского государственного университета Тел.: 8-918-97-63-263

E-mail: boltutsolga2017@gmail.com

(C) Болтуц О.А., 2020.
Исследование локальной журналистки - одно из актуальных направлений в отечественной медиалогии. Черноморская губерния, как самостоятельная административно-территориальная единица, в Российской империи появилась одной из последних, и специфика формирования ее информационного пространства требует полномасштабного и детального изучения.

Цель данной статьи - рассмотреть начальный этап формирования периодической печати Черноморской губернии и проанализировать тематические особенности публикаций, связанных с освещением повседневной жизни Черноморской губернии, на страницах газет «Черноморское побережье» и «Северный Кавказ».

Поставленная цель предполагает решение следующих задач:

- исследование информационного пространства Черноморской губернии на рубеже XIX-XX вв.;

- системно-типологический анализ отдельных периодических изданий Черноморской губернии указанного периода;

- изучение тематики публикаций в газетах «Черноморское побережье» и «Северный Кавказ».

Черноморская губерния, находясь в непосредственной близости от Кубанской области и Ставропольской губернии, долгое время не имела собственного периодического издания. Отдельные заметки о событиях и происшествиях в Новороссийске, Туапсе, Сочи, Геленджике местные жители могли прочесть на страницах екатеринодарских «Кубанских об- 
ластных ведомостей», тифлисского «Кавказа», ставрополь-кавказского «Северного Кавказа».

В 1890 г. в Новороссийске владельцем новороссийской типографии Петром Викторовичем Науменко была предпринята попытка издания первой городской газеты - «Новороссийского листка». С прошением он обратился к Начальнику Кубанской области»:

«Покорнейше прошу разрешить мне издание «Телеграмм Северного телеграфного агентства» и при них местных объявлений с разрешения местной полиции. Выход телеграмм будет ежедневный, по 75 коп. в месяц с подписчика» [Герасименко, Санеев, 1998, с. 224].

Ставропольский мещанин Науменко был представителем династии северокавказских издателей, и поэтому его желание издавать газету было вполне оправданным.

Однако содержание «Новороссийского листка» сводилось лишь к публикации зарубежных и отечественных телеграмм. Вопросы же местной жизни - политической, общественной, культурной - практически не освещались, поэтому жители Черноморской губернии попрежнему узнавали местные новости из «соседних» изданий.

Несмотря на то что «Новороссийский листок» просуществовал несколько лет, само издание не выходило за масштабы города и в информационном плане заметного следа не оставило. Так, известный исследователь кубанский журналистики Б.М. Городецкий не упоминает это издание в своем обобщающем труде - «Периодика Кубанско-Черноморского края. 1863-1925». [Городецкий, 1927]

На рубеже XIX-XX вв. Черноморская губерния стремительно развивалась, и особое место отводилось Новороссийску - губернская столица превращалась в крупный экономический центр Северного Кавказа. Необходимость в местном печатном периодическом издании была особенна высока.

Именно поэтому в конце 1902 г. в Новороссийске появилась газета «Черноморское побережье», которой удалось не только объединить местную интеллигенцию, но и привлечь профессиональных журналистов, перебравшихся в столицу Черноморской губернии из южных городов России, и стать по-настоящему интересным и влиятельным изданием данного региона.

Черноморский губернатор Евгений Николаевич Волков, оставивший значительный след в культурном развитии недавно образованной административно-территориальной единицы, поддержал идею создания местного печатного органа, в дальнейшем принимая непосредственное участие в жизни издания, и даже «согласившись быть его цензором» [Новиков, www].

Основателем и издателем ежедневной «газеты экономической, общественной и литературной» волею случая оказался служащий Владикавказской железной дороги Фёдор (Феодор) Степанович Леонтович. В качестве редактора был приглашен присяжный поверенный Михаил Григорьевич Зильберминц, ставший заметной фигурой в местной жур- 
налистике. Впоследствии Ф.С. Леонтович был утвержден «в звании второго редактора издаваемой им газеты» [Городская жизнь, 1903, № 124, с. 2].

Следуя утвержденной программе, «Черноморское побережье» сообщало своим постоянным подписчикам о правительственных распоряжениях, публиковало телеграммы Российского Телеграфного агентства и собственных корреспондентов, знакомило с заграничными и внутренними известиями, но особый интерес читательской аудитории вызывали проблемы местной общественной жизни, вести с Черноморского побережья, местная хроника и фельетоны.

Как было заявлено в «Черноморском побережье», «провинциальная печать - это наиболее верное зеркало местной жизни, наиболее верный барометр ее настроений, симпатий и антипатий. Чем ни больше каждая местная газета будет носить оригинальный характер, тем лучше и для нее, и для читателей, тем теснее будет ее связь с обывателем и с его интересами» [К вопросу о местной газете..., 1903, № 83, с. 2].

Сбалансированная редакционная политика, злободневность тематики и отсутствие конкуренции позволили изданию быстро завоевать читательскую аудиторию. Более того, информация о повседневной жизни губернии, появлявшаяся на страницах этого издания, интересовала не только местных жителей. «Черноморское побережье» с удовольствием цитировали газеты, выходившие далеко за пределами Черноморской губернии.

К примеру, первая в Северо-Кавказском регионе частная общественно-литературная и политическая газета «Северный Кавказ» неоднократно помещала на своих страницах перепечатки из «Черноморского побережья».

Пестрый калейдоскоп фактов и событий самого разного масштаба из жизни Черноморской губернии - от освещения приезда официальных лиц до криминальной хроники - чаще всего появлялся в постоянной рубрике «Областная хроника», располагавшейся на второй, иногда третьей полосе.

Ставропольские читатели узнавали о «Высочайшем приказе с описанием формы одежды для портовых матросов», возможном приезде военного министра генерал-адьютанта А.Н. Куропаткина [Областная хроника, 1903, № 116, с. 3], «запасе хлебных грузов» в Новороссийске, предложении «о продаже вин новороссийского района в Англию» [Там же, № 137, с. 3], скором открытии в Гаграх «общественной библиотекичитальни» [Там же, № 139, с. 2], преступлениях, совершённых в Новороссийске, и даже о хулиганах в Геленджике, рассылавших женщинам «анонимные письма циничного характера» [Там же, № 144, с. 3].

Особое место на страницах «Черноморского побережья» занимала тема строительства Владикавказской железной дороги.

Черноморская железная дорога была важной частью реализации проекта строительства Владикавказской железной дороги, став стратегически оправданным проектом как для Кубанской области, так и для 
Черноморской губернии. Утверждение плана предполагаемых железнодорожных линий несколько раз менялось, и железная дорога меняла свою «географию», «прокладывая путь» по территории Кубанской области и Черноморской губернии. Вопрос о населенных пунктах, через которые будет проходить железная дорога, становился принципиальным. Каждая административно-территориальная единица отстаивала свои интересы, и на страницах местных периодических изданий освещение процесса строительства Черноморской железной дороги велось с учетом региональных интересов.

Практически с момента создания «Черноморского побережья» различные аспекты строительства будущей Черноморской железной дороги получили освещение на страницах издания. Эта тема стала одной из доминирующих, и интерес к теме объясняется не только прошлой профессиональной деятельностью Ф.С. Леонтовича, связанной с службой на Владикавказской железной дороге, но и грамотной политикой в освещении данной тематики.

Более того, публикации «Черноморского побережья» вызывали острый интерес у других газет. Некоторые издания, например, «Донская речь», отстаивая интересы Области войска Донского, выступила с критикой материалов, опубликованных в «Черноморском побережье». Другие издания, например, газета «Северный Кавказ», регулярно публиковала перепечатки из «Черноморского побережья» по этому вопросу, занимая более нейтральную позицию.

Это был один из важнейших стратегических вопросов не только для Черноморской губернии, но и для Ставропольской губернии. Строительство Владикавказской железной дороги, занявшее годы, стало значимым проектом в масштабах Российской империи, и газета «Северный Кавказ» старалась держать читателей в курсе событий.

Информацию о ходе строительства Владикавказской железной дороги «Северный Кавказ» публиковал регулярно: когда недоставало собственной информации, издание цитировало «коллег», среди которых было и «Черноморское побережье».

Так, в «Областной хронике» «Северный Кавказ» сообщал:

«Новороссийск. "Черноморское побережье" слышало, что вопрос о Черноморской железной дороге, так живо интересующий новороссийских обывателей, вероятнее всего, разрешится так...» [Областная хроника, 1903, № 136, с. 2]. А в следующем номере очередная перепечатка из «Черноморского побережья» сообщала новости по «вопросу о предъявлении иска к Владикавказской железной дороге» [Там же, № 137, с. 3].

Впрочем, само «Черноморское побережье» активно расширяло аудиторию и стремилось найти своих читателей за пределами губернии. Так, издание стремилось знакомить читателей Ставропольской губернии с повседневной жизнью Новороссийска, Геленджика, Сочи, Туапсе, Гагр напрямую, и поэтому публиковало объявление о подписке в газете «Северный Кавказ». 
Таким образом, можно прийти к выводу, что материалы, связанные с освещением повседневной жизни Черноморской губернии, органично вписывались в тематическую палитру газеты «Северный Кавказ», расширяя ее контент и отвечая запросам читателей.

\section{Литература}

Герасименко А., Санеев $C$. Новороссийск - от укрепления к губернскому городу. Краснодар: Эдви, 1998. 496 с.

Городеикий Б.М. Периодика Кубанско-Черноморского края. 1863-1925. Краснодар, Б.и., 1927. 72 с. C.2.

Городская жизнь // Черноморское побережье. Новороссийск. 1903. № 124.

Новиков С. Г. Губернатор Волков - человек и памятник // Официальный Новороссийск. 03.05.2019. [Электронный ресурс]. URL: http://ofnvrsk.ru:4000/ news/item/2711 (дата обращения 20.10.2019).

К вопросу о местной газете // Черноморское побережье. Новороссийск, 1903. № 83. C. 2.

Областная хроника // Северный Кавказ. Ставрополь-Кавказский. 1903. № 116 . С. 3.

Областная хроника // Северный Кавказ. Ставрополь-Кавказский. 1903. № 136. C. 2.

Областная хроника // Северный Кавказ. Ставрополь-Кавказский. 1903. № 137. С. 3.

Областная хроника // Северный Кавказ. Ставрополь-Кавказский. 1903. № 139. С. 2.

Областная хроника // Северный Кавказ. Ставрополь-Кавказский. 1903. № 144 . С. 3.

Объявление о подписке // Черноморское побережье. Новороссийск, 1903. № 8. C.1.

Слуцкий А.И. Архивный фонд Канцелярии Начальника Кубанской области и Наказного Атамана Кубанского Казачьего войска как источник изучения истории регионального книжного дела (1870-1917) // Мы нашей истории пишем страницы: VII историко-библиотечные чтения «О прошлом память сохраняя» / М-во культуры Респ. Адыгея, Нац. б-ка Респ. Адыгея; сост. Ф. А. Тешева. Майкоп, 2014. С. 5-22.

\section{References}

Gerasimenko A., Saneyev S. Novorossiysk - ot ukrepleniya $k$ gubernskomu gorodu. Krasnodar, 1998. 496 p. (In Russian).

Gorodetskiy B.M. Periodika Kubansko-Chernomorskogo kraya. 1863-1925. Krasnodar, 1927. 72 p. (In Russian).

Gorodskaya zhizn'. Chernomorskoye poberezh'e. Novorossiysk, 1903, № 124, p. 2. (In Russian).

Novikov S. G. Gubernator Volkov - chelovek i pamyatnik. Ofitsial'nyy Novorossiysk. 03.05.2019. Available at: http://ofnvrsk.ru:4000/news/item/2711 (accessed 20.10.2019). (In Russian).

K voprosu o mestnoy gazete. Chernomorskoye poberezh'e. Novorossiysk, 1903, no. 83, p. 2. (In Russian).

Oblastnaya khronika. Severnyy Kavkaz. Stavropol'-Kavkazskiy, 1903, no. 116, p. 3. (In Russian). 
Oblastnaya khronika. Severnyy Kavkaz. Stavropol'-Kavkazskiy, 1903, no. 136, p. 2. (In Russian).

Oblastnaya khronika. Severnyy Kavkaz. Stavropol'-Kavkazskiy, 1903, no. 137, p. 3. (In Russian).

Oblastnaya khronika. Severnyy Kavkaz. Stavropol'-Kavkazskiy, 1903, no. 139, p. 2. (In Russian).

Oblastnaya khronika. Severnyy Kavkaz. Stavropol'-Kavkazskiy, 1903, no. 144, p. 3. (In Russian).

Ob» yavleniye o podpiske. Chernomorskoye poberezh'e. Novorossiysk, 1903, no. 8, p. 1. (In Russian).

Slutskiy A.I. Arkhivnyy Fond Kantselyarii Nachal'nika Kubanskoy oblasti i Nakaznogo Atamana Kubanskogo Kazach'ego voyska kak istochnik izucheniya istorii regional'nogo knizhnogo dela (1870-1917). My nashey istorii pishem stranitsy: VII istoriko-bibliotechnyye chteniya «O proshlom pamyat' sokhranyaya». M-vo kul'tury Resp. Adygeya, Nats. b-ka Resp. Adygeya; sost. F. A. Tesheva. Maykop, 2014, pp. 5-22. (In Russian).

Olga A. Boltuts (Krasnodar, Russian Federation)

\section{Daily Life of the Black Sea Province on the Pages of the Newspaper «North Caucasus»}

The article analyzes the periodicals of the Black Sea province at the turn of the XIX-XX centuries, it considers the features of the editorial policy of the newspaper «North Caucasus» in highlighting the daily life of the Black Sea province.

Key words: Black Sea province, periodicals, F.S. Leontovich, Novorossiysk leaflet, Black Sea coast, North Caucasus, editorial policy, everyday life.

Olga A. Boltuts - Ph. D. of Philology, associate professor. Faculty of Journalism, Department of History and Legal Regulation of Mass Communications. Kuban State University. Phone: 8-918-97-63-263, e-mail: boltutsolga2017@gmail.com. 